\title{
AUDIT SISTEM INFORMASI
}

SMK FARMASI CENDIKIA FARMA HUSADA

(DEVISI WAKA SCSW)

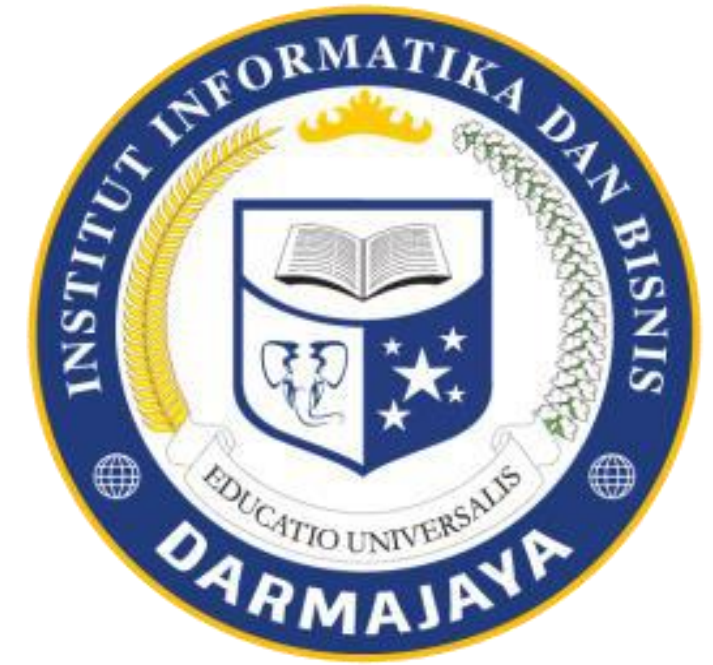

Wayan Okta Sari

1611050023

INSTITUT INFORMATIKA DAN BISNIS DARMAJAYA 2019 


\section{BAB I}

\section{SEJARAH SMK FARMASI CENDIKIA FARMA HUSADA}

Sekolah menengah kejuruan (SMK) farmasi cendikia farma husada dirintis sejak mei 2010 oleh praktisi apotikermuda yang berfossional dan kompeten dibidang kefarmasian yaitu Bpk.Hi ardyansyah khauripan, M,Si., Apt dibawah naungan yayasan cendikia farma husada.

SMK farmasi candika husada ini merupakan smk farmasi yang pertama berada diBandar Lampung yang kemuduan menjadi pelopor perkembangan smk farmasi diprovinsi Lampung. Sebagai sekolah farmasi plopor, SMK farmasi cendika terus melakukan pengebangan sistem kependiddikan farmasi sehinga tampil menjadi SMK farmasi favorit dan unggul.

Secara geografis gedung SMK farmasi cendikia farma husada terletak dilingkingan pemungkiman penduduk dikota Bandar Lampung tempatnya dijalan pulau enggano No.99, Kelurahan Sukabumi, Kecamatan Sukabumi, kota Bandar Lampung. Sekolah ini berdiri diatas tanah seluas $\pm 1.878 \mathrm{~m}^{2}$.

Secara topografi wilayah SMK farmasi cendikia farma husada merupakan daerah dataran yang subur dengan sumber air yang baik. Akses menuju sekolah dapat ditempuh dengan roda empat maupun roda dua.

Tata ruang gedung SMK farmasi candikia farma husada dibangun dengan konsep modren dan humanis sehingga interaksi guru dan siswa dalam proses pendidikan dapat terbangun dan terpelihara dengan baik. SMK farmasi candikia farma husada menyajikan fasilitas belajar yang nyaman dan memadai yaitu:

1. Gedung sekolah yang fresh dengan status milik sendiri (yayasan cendikia farma husada).

2. Laborarorium praktikum farmasetika yang lengkap dan ber-AC.

3. Ruang kelas multimedia (audio-visual/lcd proyektor) dan ber-AC.

4. Wifi/host spot area.

5. Perpustakaan

6. Kantin yang bersih dan nyaman

7. Mushola

8. Ruang perawatan kesehatan

9. Ruang sekretariat bersama unit kegiatan siswa

10. Lapangan bulu tangkis dan sepak takraw

11. Area parkir dan taman

12. Apotek pendidikan

13. Kebun tanaman obat

14. Fasilitas sanitasi yang baik.

Letak sekolah yang tidak terlalu dekat dengan jalan raya menjadi nilai positif secara ekologis, sekolah tiadak bisik dan mengurangi kontaminasi dari polusi timbal yang berbahaya bagi pernafasan. Letak sekolah yang lebih tinggi dari jalan umum serta sistem irigasi yang lancar dan baik dapat menghindari sekolah dari banjir pada musim hujan. Tanaman dan sirkulasi 
udara yang ditata dengan baik sangat mendukung kenyamanan dalam proses belajar selama masa pendididkan serta dapat menjaga kesehatan dilingkingan sekolah.

\section{VISI DAN MISI SMK FARMASI CENDIKIA FARMA HUSADA}

* VISI

"mewujudkan sekolah yang unggul dalam mencetak asisten tenaga kefarmasian yang kompeten,disiplin,religius dan berdaya saing".

MISI

1. Membangkitan kekuatan moral dan kesadaran tentang keberadaan Allah SWT Yang Masha Esa dan sadar bahwa setiap kehidupan akan dipertanggung jawabkan .

2. Menyelenggarakan proses pendidikan yang professional dan berkualitas agar peserta didik menjadi asisten tenaga kefarmasian yang berkemampuan akademik dan berdaya asing.

3. Melakukan pendidikan dan pengembangan karakter peserta didik agar memiliki kecerdasan emosional dan spiritual yang baik dalam menerapkan ilmu kefarmasian dimasyarakat.

4. Menggunakan teknologi informasi dalam penyelenggaraan pendidikan serta mengupayakan kemampuan penggunananya kepada peserta didik untuk meningkatkan daya asing diera digital.

\section{FRESTASI SMK FARMASI CENDIKIA FARMA HUSADA}

1. Juara $1 \mathrm{lks}$ tingkat kota bandar lampung

2. Juara 1 olimpiade sains terapan (ost) bidang biologi se provinsi lampung

3. Juara 1 lomba kompetisi siswa (lks) se provinsi lampung

4. Smk faramasi cendikia farma husada mendapat penghargaan dari mentri pendididkan nasional RI sebagai sekolah berintegritas tinggi tahun 2015

\section{SMK FARMASI CENDIKIA FARMA HUSADA BERGERAK DIBIDANG}

“Yayasan Cendikia Farma Husada”

\section{DENAH LOKASI SMK FARMASI CENDIKIA FARMA HUSADA}

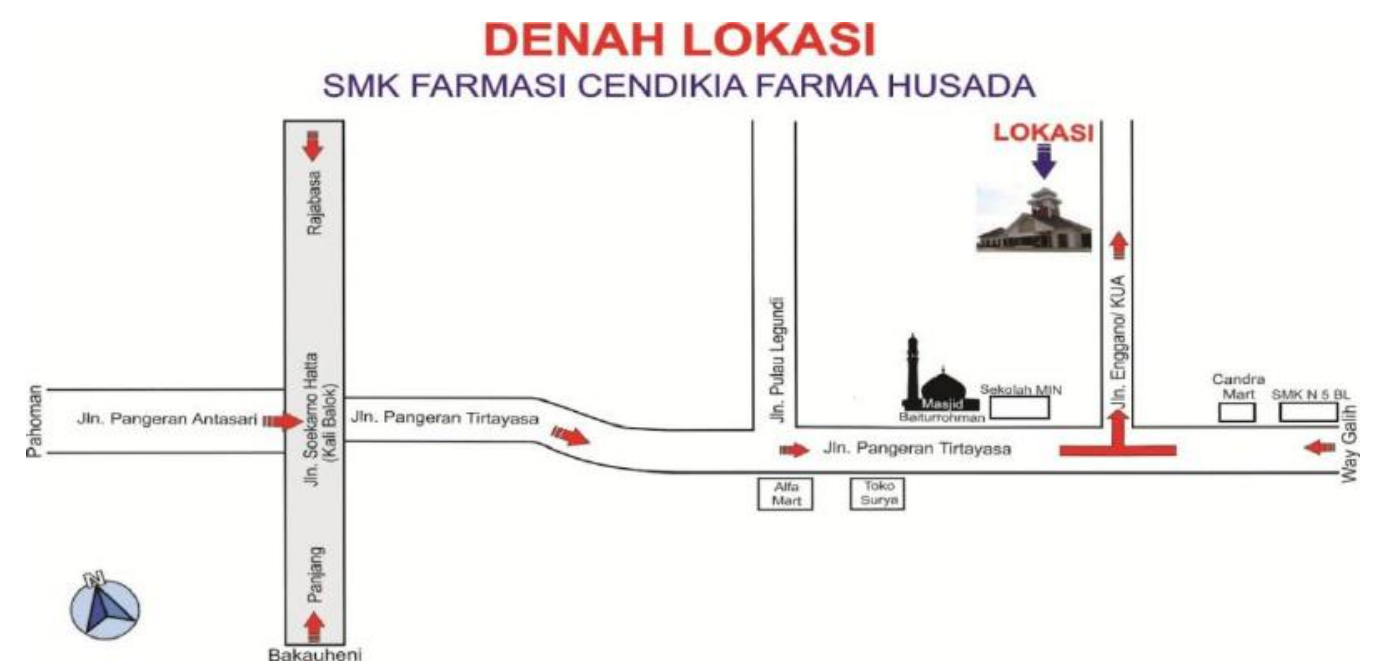




\section{BAB II}

\section{STRUKTUR SMK FARMASI CENDIKIA FARMA HUSADA}

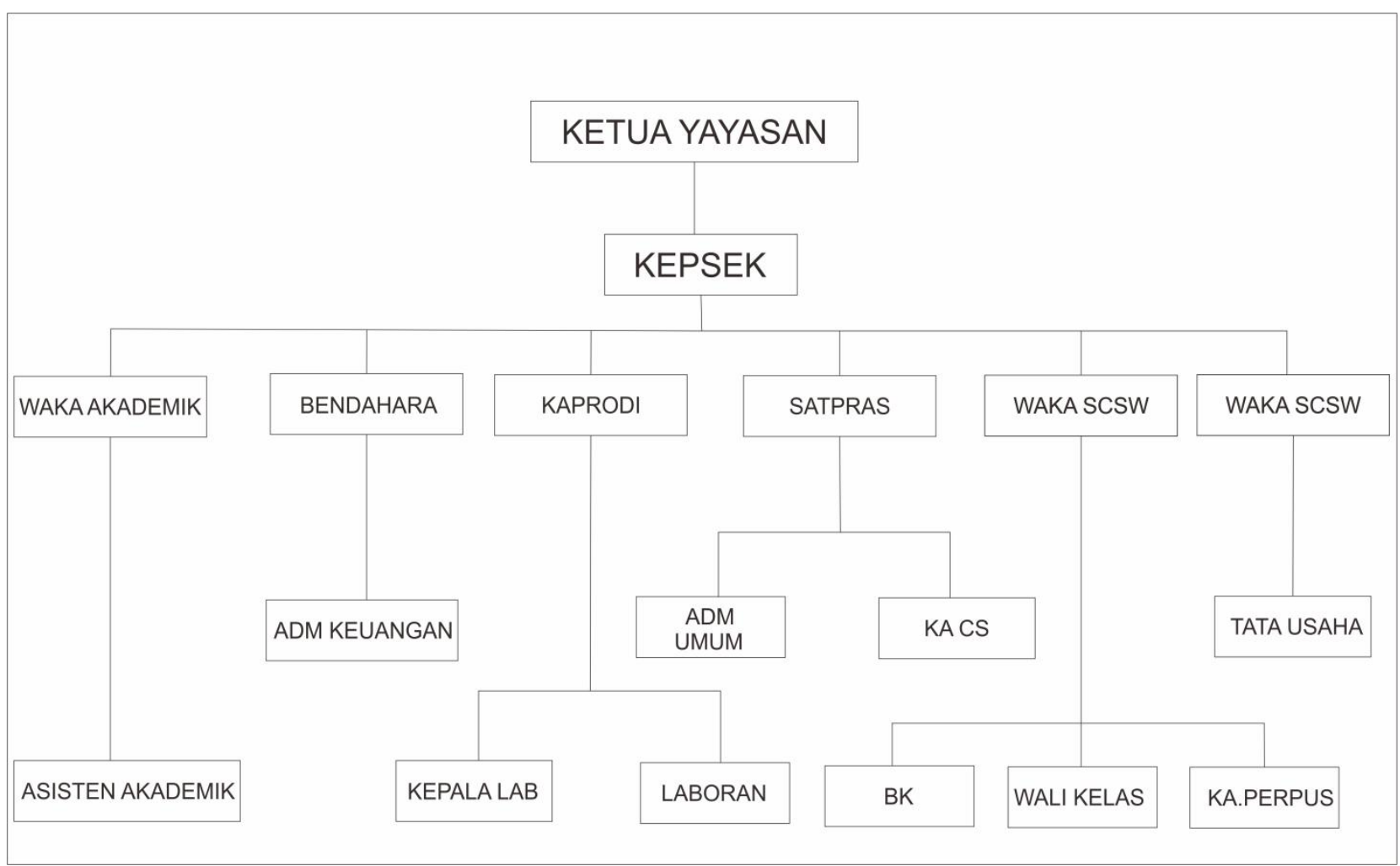

\section{STRUKTUR DIVISI WAKA SCSW}

STRUKTUR WAKA SCSW

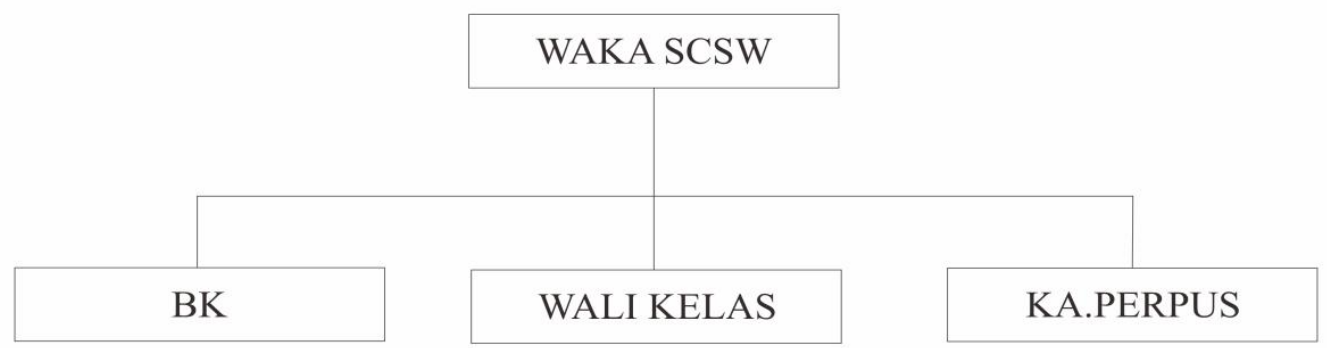




\section{BAB III}

\section{- Quisioner Manajement}

\begin{tabular}{|l|c|c|c|c|c|c|c|c|c|c|c|}
\hline NO & \multicolumn{4}{|c|}{ Performance } & \multicolumn{4}{c|}{ Expectasi } \\
\cline { 3 - 9 } & SB & B & C & TB & STB & SB & B & C & TB & STB \\
\hline
\end{tabular}

P04.1 Rangka proses IT

\begin{tabular}{|l|l|l|l|l|l|l|l|l|l|l|l|}
\hline 1. & $\begin{array}{l}\text { Bagaimana tingkat kematangan } \\
\text { kinerja yang dimiliki oleh kepala } \\
\text { bidang }\end{array}$ & & & & & & & & & & \\
\hline 2. & $\begin{array}{l}\text { Bagaimana struktur proses dan } \\
\text { hubungan kepala bidang dengan } \\
\text { siswa/i }\end{array}$ & & & & & & & & & & \\
\hline
\end{tabular}

P04.2 komite strategi IT

\begin{tabular}{|l|l|l|l|l|l|l|l|l|l|l|l|}
\hline 1. & $\begin{array}{l}\text { Bagaimana strategi memberi sebuah } \\
\text { arahan terhadap siswa/i nya }\end{array}$ & & & & & & & & & & \\
\hline 2. & $\begin{array}{l}\text { Bagaimana investasi sebagai kepala } \\
\text { bidang untuk menegakan kinerja yang } \\
\text { sudah ditugaskan masing-masing oleh } \\
\text { kepala devisi }\end{array}$ & & & & & & & & & & \\
\hline
\end{tabular}

P04.3 komite pengarah IT

\begin{tabular}{|l|l|l|l|l|l|l|l|l|l|l|l|}
\hline 1. & $\begin{array}{l}\text { Apakah perdevisi atau kepala bidang } \\
\text { jika ada sebuah konflik sudah } \\
\text { mengatasi dengan baik atau sesuai } \\
\text { prosedur yang ada diyayasan ini }\end{array}$ & & & & & & & & & & \\
\hline 2. & $\begin{array}{l}\text { Apakah pemantauan setiap devisi } \\
\text { atau kepala bidang sudah terlaksana } \\
\text { atas peningkatan jasa yang diberikan } \\
\text { kepada siswa/i }\end{array}$ & & & & & & & & & & \\
\hline
\end{tabular}

P04.4 penempatan organisasi pada fungsi IT

\begin{tabular}{|l|l|l|l|l|l|l|l|l|l|l|l|}
\hline 1. & $\begin{array}{l}\text { Bagaimana penempatan struktur } \\
\text { organisasi yang ada didevisi waka } \\
\text { scsw ini,apakah sudah benar/sesuai } \\
\text { bidang }\end{array}$ & & & & & & & & & & \\
\hline 2. & $\begin{array}{l}\text { Bagaimana strategi struktur organisasi } \\
\text { yang ada pada devisi waka scsw } \\
\text { ini,apakah sudah teroprasional } \\
\text { dengan baik }\end{array}$ & & & & & & & & & & \\
\hline
\end{tabular}

P04.5 struktur organisasi IT

\begin{tabular}{|l|l|l|l|l|l|l|l|l|l|l|l|}
\hline 1. & $\begin{array}{l}\text { Bagaimana sususnan struktur } \\
\text { organisasi devisi waka scsw yang ada } \\
\text { di yayasan farmasi ini }\end{array}$ & & & & & & & & & \\
\hline 2. & $\begin{array}{l}\text { Apakah struktur organisasi internal } \\
\text { waka scsw ini sudah terproses dengan } \\
\text { baik }\end{array}$ & & & & & & & \\
\hline
\end{tabular}

P04.6 penentuan peran dan tanggung jawab

\begin{tabular}{l|l}
1. & Bagaimana peran seorang waka
\end{tabular} 


\begin{tabular}{|l|l|l|l|l|l|l|l|l|l|l|l|}
\hline & $\begin{array}{l}\text { scsw,BK,wali kelas dan Ka.perpus } \\
\text { terhadap siswa yang ada diyayasan ini }\end{array}$ & & & & & & & & & & \\
\hline 2. & $\begin{array}{l}\text { Bagaimana tanggung jawab perdevisi } \\
\text { terhadap tanggung jawab sebagai } \\
\text { masing-masing bidang struktur }\end{array}$ & & & & & & & & & & \\
\hline
\end{tabular}

P04.7 Pertanggungjawaban terhadap jaminan mutu IT

\begin{tabular}{|l|l|l|l|l|l|l|l|l|l|l|l|}
\hline 1. & $\begin{array}{l}\text { Bagaimana pertanggungjawaban } \\
\text { dalam kinerja setiap kepala } \\
\text { bidang,BK, wali kelas,Ka.perpus }\end{array}$ & & & & & & & & & & \\
\hline 2. & $\begin{array}{l}\text { Apakah jaminan mutu yang ada } \\
\text { diyayasan farmasi ini sudah } \\
\text { tertanggungjawabi dengan baik }\end{array}$ & & & & & & & & & & \\
\hline
\end{tabular}

P04.8 Pertanggungjawaban terhadap resiko,keamanan dan pengabulan

\begin{tabular}{|l|l|l|l|l|l|l|l|l|l|l|l|}
\hline 1. & $\begin{array}{l}\text { Bagaimana keamanan sistem } \\
\text { informasi,keamanan fisik, dan } \\
\text { kepatuhanyang diterpakan kepada } \\
\text { siswa/i }\end{array}$ & & & & & & & & & & \\
\hline 2. & $\begin{array}{l}\text { Apakah resiko keamanan dan } \\
\text { pengabulan yang ada diyayasan } \\
\text { farmasi ini sudah terkomunikasi atau } \\
\text { terlaksana dengan baik }\end{array}$ & & & & & & & & & & \\
\hline
\end{tabular}

P04.9 Kepemilikan data dan sistem

\begin{tabular}{|l|l|l|l|l|l|l|l|l|l|l|l|}
\hline 1. & $\begin{array}{l}\text { Apakah data-data siswa/i yang ada } \\
\text { disetiap kepala bidang devisi sudah } \\
\text { tersusun dengan baik }\end{array}$ & & & & & & & & & & \\
\hline 2. & $\begin{array}{l}\text { Bagaimana pengelarifikasian sistem } \\
\text { yang ada didalam setiap perdevisi } \\
\text { atau kepala bidang }\end{array}$ & & & & & & & & & & \\
\hline
\end{tabular}

P04.10 pengawasan

\begin{tabular}{|l|l|l|l|l|l|l|l|l|l|l|l|}
\hline 1. & $\begin{array}{l}\text { Bagaimana upaya pengawasan setiap } \\
\text { kepala bidang atau devisi terhadap } \\
\text { siswa/i }\end{array}$ & & & & & & & & & & \\
\hline $\begin{array}{l}\text { Bagaimana peran dan tanggung jawab } \\
\text { perkepala bidang terhadap } \\
\text { pengawasan diyayasan ini }\end{array}$ & & & & & & & & \\
\hline
\end{tabular}

P04.11 Pemisahan tugas

\begin{tabular}{|l|l|l|l|l|l|l|l|l|l|}
\hline 1. & $\begin{array}{l}\text { Apakah perdevisi sudah menjalakan } \\
\text { tugas mereka masing-masing dengan } \\
\text { baik }\end{array}$ & & & & & & & & \\
\hline 2. & $\begin{array}{l}\text { Bagaimana cara perdevisi } \\
\text { mempertanggungjawabkan tugas } \\
\text { yang sudah dinaungi masing-masing } \\
\text { devisi }\end{array}$ & & & & & & & & \\
\hline
\end{tabular}


P08.1 sistem pengelolaan mutu (quality managment system-QMS)

\begin{tabular}{|l|l|l|l|l|l|l|l|l|l|}
\hline 1. & $\begin{array}{l}\text { Bagaimana pengelolaan kualitas dan } \\
\text { kritria terhadap siswa/i diyayasan } \\
\text { farmasi ini }\end{array}$ & & & & & & & & \\
\hline 2. & $\begin{array}{l}\text { Bagaimana pengelolaan } \\
\text { kebijakan,mendeteksi,mengoreksi,dan } \\
\text { mencengah prilaku siswa yang kurang } \\
\text { baik }\end{array}$ & & & & & & & & \\
\hline
\end{tabular}

P08.2 peraktik standar dan kualitas

\begin{tabular}{|l|l|l|l|l|l|l|l|l|l|}
\hline 1. & $\begin{array}{l}\text { Bagaimana prosedur yang di tawarkan } \\
\text { kesiswa apakah baik atau tidak }\end{array}$ & & & & & & & & \\
\hline $\begin{array}{l}\text { Bagaimana bimbingan atau araan } \\
\text { yang diberikan kesiswa/i sudah cukup } \\
\text { baik }\end{array}$ & & & & & & & & & \\
\hline
\end{tabular}

P08.3 standar pengembangan dan pemerolehan

\begin{tabular}{|l|l|l|l|l|l|l|l|l|l|}
\hline 1. & $\begin{array}{l}\text { Bagaimana pengembangan dan } \\
\text { pemerolehan terhadap sirklus yang } \\
\text { ada di yayasan farmasi ini terhadap } \\
\text { siswa }\end{array}$ & & & & & & & & \\
\hline $\begin{array}{l}\text { Bagaimana kinerja pengujian } \\
\text { terhadap siswa sudah terintgrasi } \\
\text { dengan baik }\end{array}$ & & & & & & & & & \\
\hline
\end{tabular}

P08.4 fokus pelangan

\begin{tabular}{|l|l|l|l|l|l|l|l|l|l|}
\hline 1. & $\begin{array}{l}\text { Bagaimana peran seorang BK } \\
\text { terhadap siswa diyayasan farmasi ini }\end{array}$ & & & & & & & & \\
\hline 2. & $\begin{array}{l}\text { Bagaimana tanggung jawab seorang } \\
\text { wali kelas jika ada konflik terhadap } \\
\text { sesama siswa/i diyayasan farmasi ini }\end{array}$ & & & & & & & & \\
\hline
\end{tabular}

P08.5 Peningkatan yang berkelanjutan

\begin{tabular}{l|l|l|l|l|l|l|l|l|l|l|}
\hline 1. & $\begin{array}{l}\text { Bagaimana mutu perdevisi terhadap } \\
\text { siswa/i yang ada diyayasan farmasi ini } \\
\text { mengalami peningkatan }\end{array}$ & & & & & & & & & \\
\hline 2. & $\begin{array}{l}\text { Bagaimana peningkatan seorang waka } \\
\text { scsw terhadap siswa }\end{array}$ & & & & & & & & & \\
\hline
\end{tabular}

P08.6 Pengukuran pengawasan dan penijauan kualitas

\begin{tabular}{|l|l|l|l|l|l|l|l|l|l|}
\hline 1. & $\begin{array}{l}\text { Bagaimana pengawasan Bk terhadap } \\
\text { siswa diyayasan ini }\end{array}$ & & & & & & & \\
\hline 2. & $\begin{array}{l}\text { Bagaimana pemantauan dan } \\
\text { pencataan BK, wali kelas dan } \\
\text { KA.perpus terhadap dokumen } \\
\text { ataupun informasi dari siswa/i }\end{array}$ & & & & & & & & \\
\hline
\end{tabular}


- Quisioner user

\begin{tabular}{|c|c|c|c|c|c|c|c|c|c|c|c|}
\hline \multirow{2}{*}{$\bullet \mathrm{NO}$} & \multirow[t]{2}{*}{ Pernyataan } & \multicolumn{5}{|c|}{ Performance } & \multicolumn{5}{|c|}{ Expectasi } \\
\hline & & SB & B & $\mathrm{C}$ & TB & STB & SB & B & $\mathrm{C}$ & TB & STB \\
\hline \multicolumn{12}{|c|}{ P04 mendefinisikan proses,organisasi,dan hubungan IT } \\
\hline \multicolumn{12}{|l|}{ P04.1 Rangka proses IT } \\
\hline 1. & $\begin{array}{l}\text { Bagaimana tingkat kinerja } \\
\text { yang dimiliki oleh guru BK } \\
\text { kepada siswa/i }\end{array}$ & & & & & & & & & & \\
\hline 2. & $\begin{array}{l}\text { Bagaimana struktur proses } \\
\text { dan hubungan kepala } \\
\text { bidang dengan siswa/i }\end{array}$ & & & & & & & & & & \\
\hline
\end{tabular}

P04.2 komite strategi IT

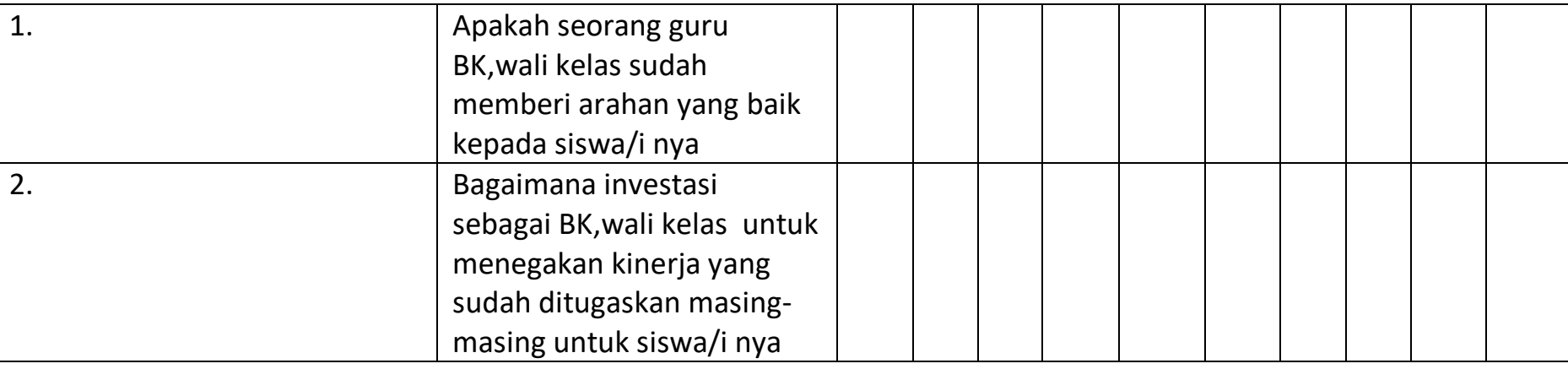

P04.3 komite pengarah IT

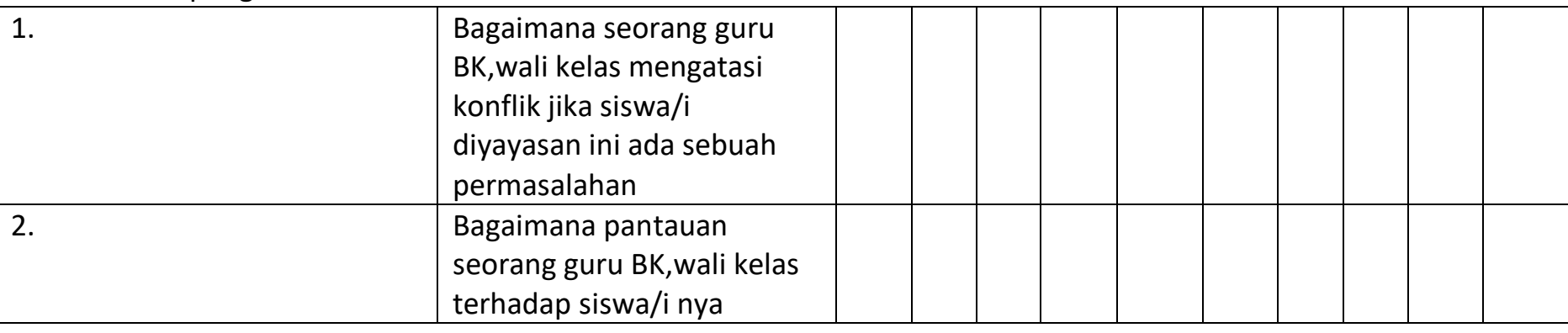

P04.4 penempatan organisasi pada fungsi IT

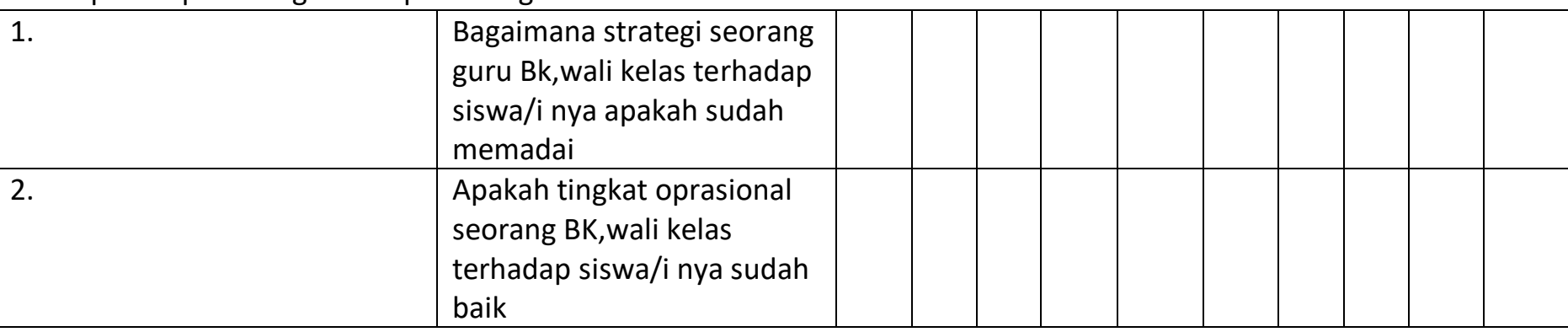

P04.5 struktur organisasi IT

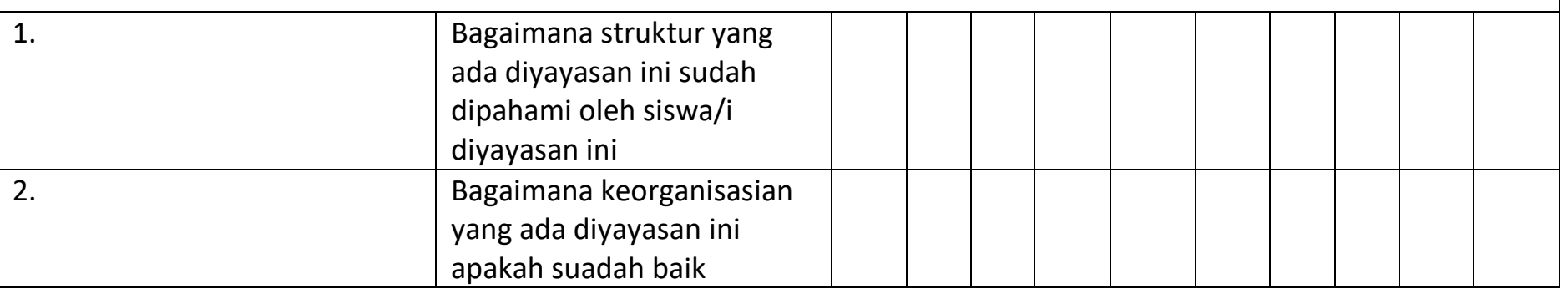


P04.6 penentuan peran dan tanggung jawab

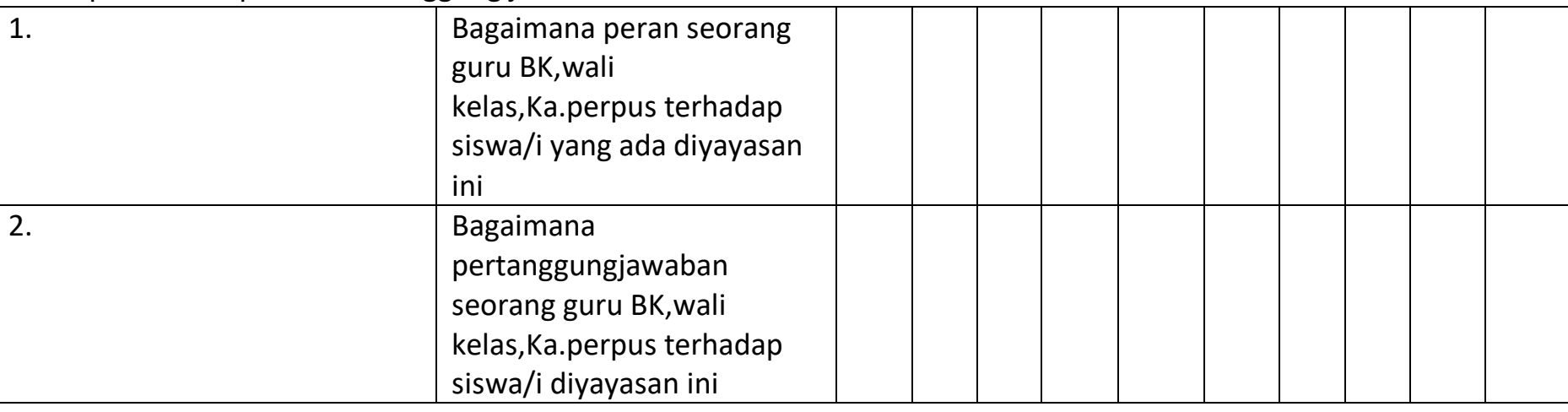

P04.7 Pertanggungjawaban terhadap jaminan mutu IT

\begin{tabular}{|l|l|l|l|l|l|l|l|l|l|l}
\hline 1. & $\begin{array}{l}\text { Bagaimana tanggapan } \\
\text { seorang guru BK, wali kelas } \\
\text { jika ada kendala pada } \\
\text { siswa/i nya }\end{array}$ & & & & & & & & & \\
\hline 2. & $\begin{array}{l}\text { Apakah komunikasi } \\
\text { pertanggungjawaban } \\
\text { jaminan mutu diyayasan ini } \\
\text { sudah terlaksana }\end{array}$ & & & & & \\
\hline
\end{tabular}

P04.8 Pertanggungjawaban terhadap resiko,keamanan dan pengabulan

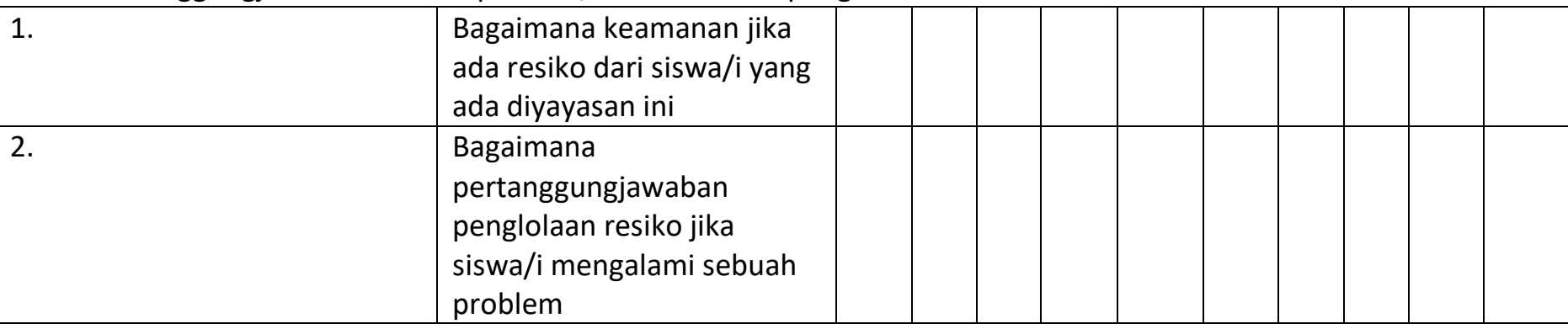

P04.9 Kepemilikan data dan sistem

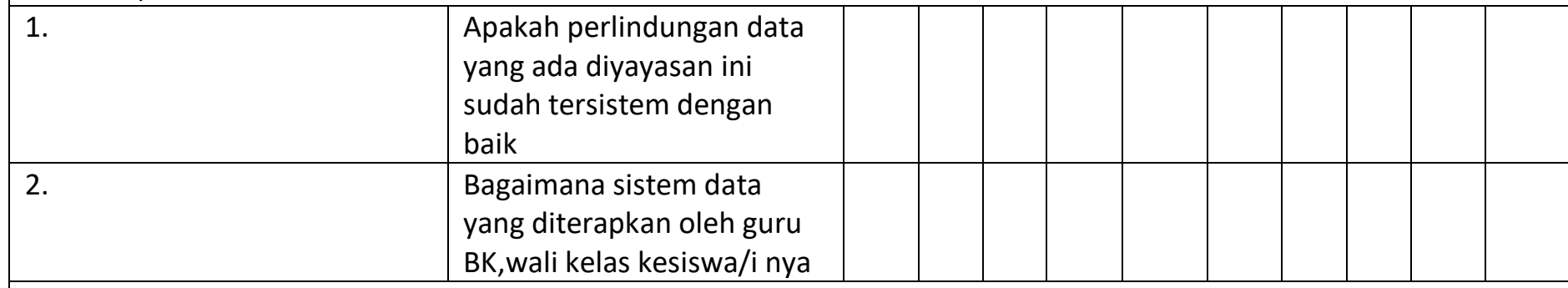

P04.10 pengawasan

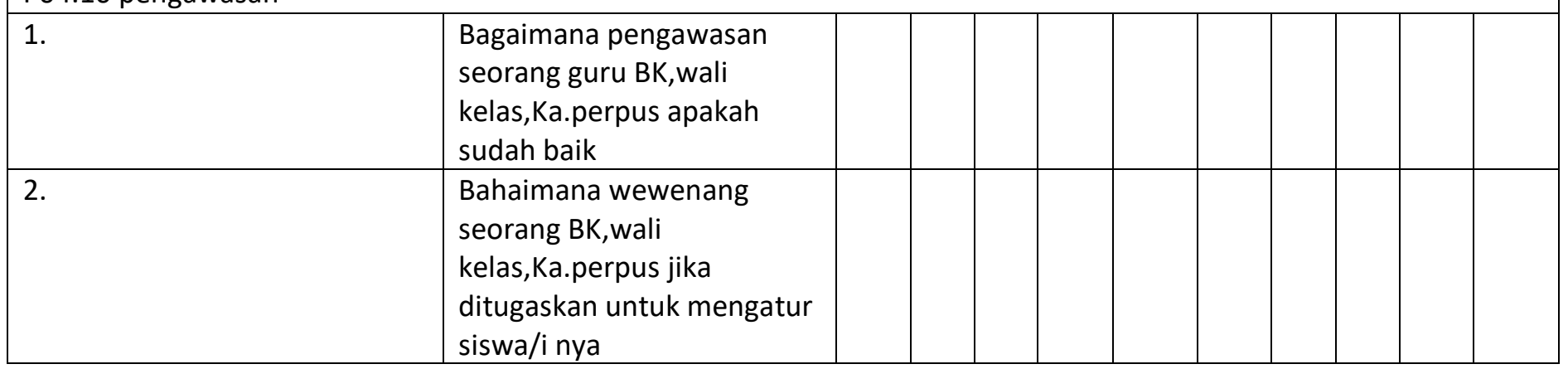


P04.11 Pemisahan tugas

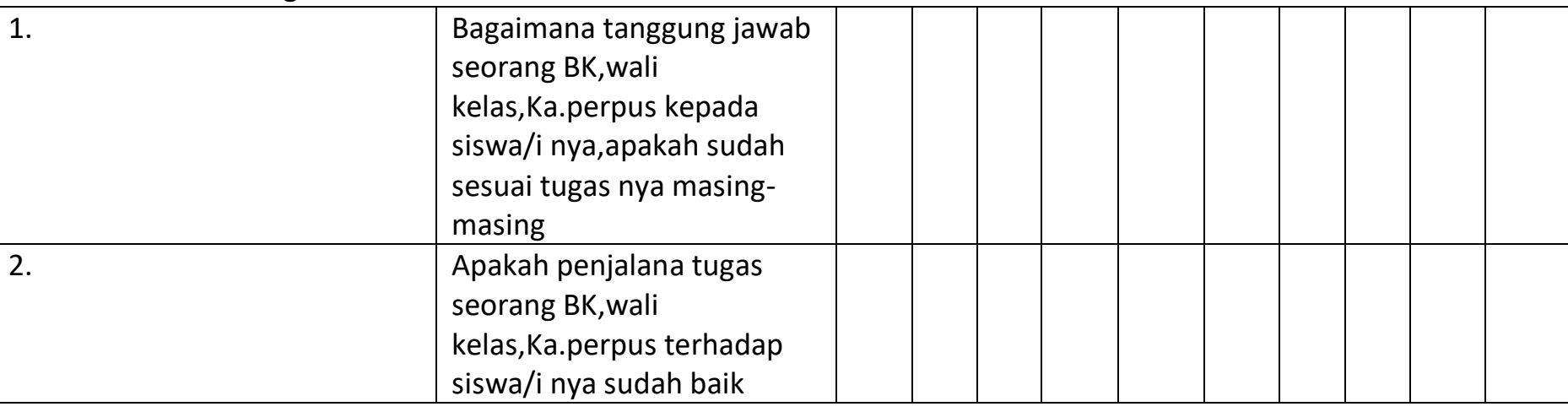

\section{P08 Mengelola Kualitas}

P08.1 sistem pengelolaan mutu (quality managment system-QMS)

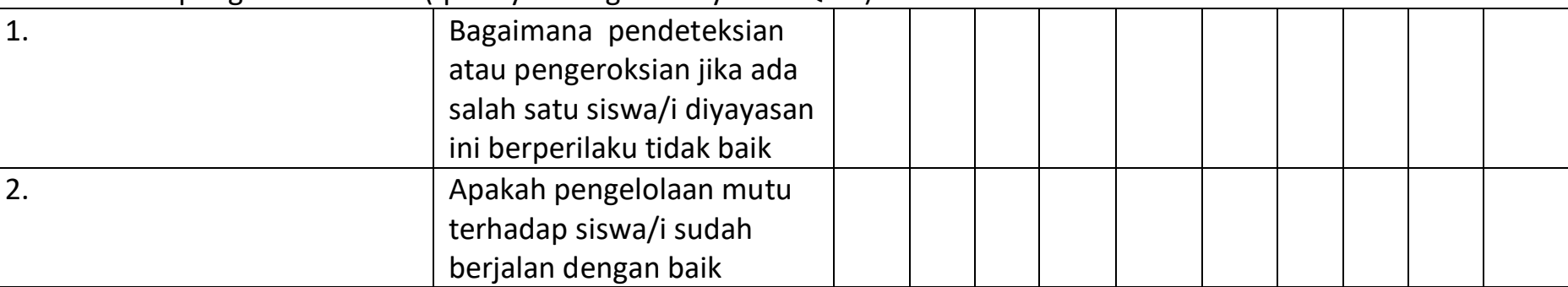

P08.2 peraktik standar dan kualitas

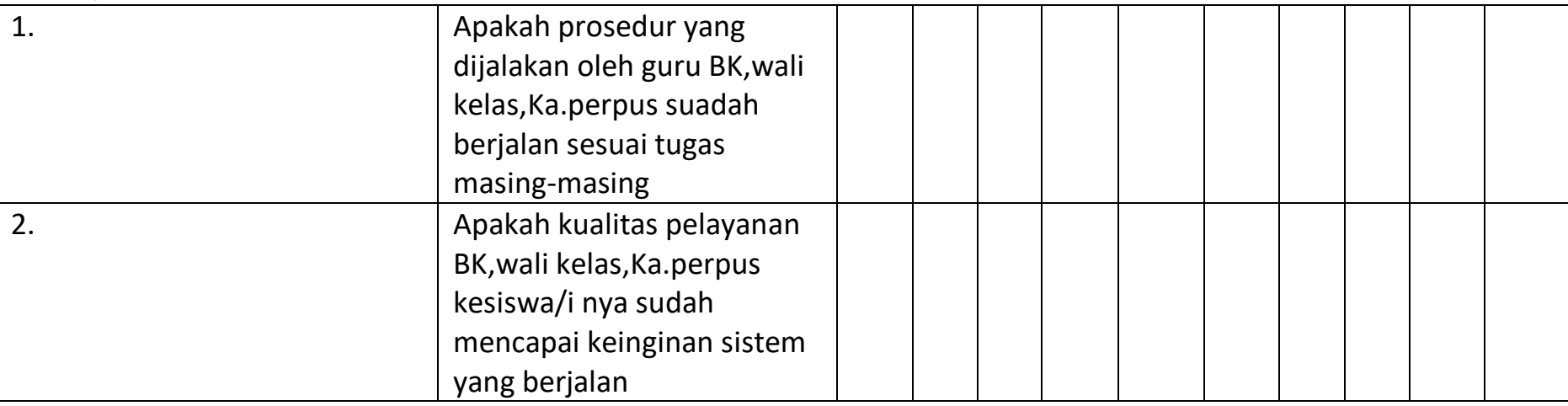

P08.3 standar pengembangan dan pemerolehan

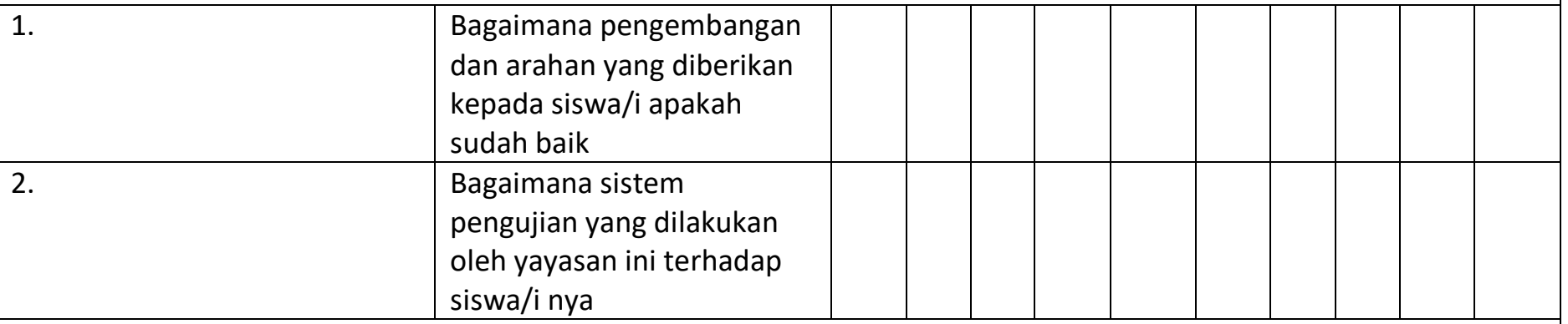

P08.4 fokus pelangan

\begin{tabular}{|l|l|l|l|l|l|l|l|l|}
\hline 1. & $\begin{array}{l}\text { Bagaimana pengelolaan } \\
\text { kualitas jika ada konflik } \\
\text { terhadap siswa/i }\end{array}$ & & & & & & & \\
\hline 2. & $\begin{array}{l}\text { Bagaimana penyelsaian } \\
\text { konflik jika ada sebuah } \\
\text { konflik disiswa/i yayasan ini }\end{array}$ & & & & & & & \\
\hline
\end{tabular}




\section{P08.5 Peningkatan yang berkelanjutan}

\begin{tabular}{|l|l|l|l|l|l|l|l|l|}
\hline 1. & $\begin{array}{l}\text { Bagaimana mutu seorang } \\
\text { guru BK,wali } \\
\text { kelas,Ka.perpus kepada } \\
\text { siswa/i yang ada di yayasan } \\
\text { ini }\end{array}$ \\
\hline $\begin{array}{l}\text { Bagaimana peningkatan } \\
\text { pengawasa seorang guru } \\
\text { Bk,wali kelas terhadap } \\
\text { siswa/i nya }\end{array}$ & & & & & & & & \\
\hline
\end{tabular}

P08.6 Pengukuran pengawasan dan penijauan kualitas

\begin{tabular}{|l|l|l|l|l|l|l|l|l|}
\hline 1. & $\begin{array}{l}\text { Bagaimana pengawasan } \\
\text { seorang guru BK,wali kelas } \\
\text { terhadap siswa/i yang ada } \\
\text { diyayasan ini }\end{array}$ & & & & & & & \\
\hline $\begin{array}{l}\text { Bagaimana peninjuan } \\
\text { kualitas atau pemantauan } \\
\text { seorang BK,wali kelas } \\
\text { terhadap siswa/i nya }\end{array}$ & & & & & & & & \\
\hline
\end{tabular}


BAB VI

REKAP HASIL KUESIONER

USER

\begin{tabular}{|c|c|c|c|c|c|c|c|}
\hline & & No & SB & $\mathrm{B}$ & $C$ & TB & STB \\
\hline 1 & P04.1 & 1,1 & 3 & 5 & 1 & & \\
\hline 2 & & 1,2 & 1 & 3 & 5 & & \\
\hline 3 & P04.2 & 2,1 & 2 & 6 & 1 & & \\
\hline 4 & & 2,2 & & 4 & 5 & & \\
\hline 5 & P04.3 & 3,1 & 3 & 5 & 1 & & \\
\hline 6 & & 3,2 & 1 & 6 & 2 & & \\
\hline 7 & P04.4 & 4,1 & 1 & 1 & 7 & & \\
\hline 8 & & 4,2 & & 1 & 8 & & \\
\hline 9 & P04.5 & 5,1 & 1 & 6 & 2 & & \\
\hline 10 & & 5,2 & 2 & 2 & 5 & & \\
\hline 11 & P04.6 & 6,1 & 2 & 7 & & & \\
\hline 12 & & 6,2 & 5 & 3 & 1 & & \\
\hline 13 & P04.7 & 7,1 & & 6 & 3 & & \\
\hline 14 & & 7,2 & & 4 & 5 & & \\
\hline 15 & P04.8 & 8,1 & 2 & 4 & 3 & & \\
\hline 16 & & 8,2 & 1 & 8 & & & \\
\hline 17 & P04.9 & 9,1 & & 5 & 4 & & \\
\hline 18 & & 9,2 & & 3 & 5 & 1 & \\
\hline 19 & P04.10 & 10,1 & 3 & 6 & & & \\
\hline 20 & & 10,2 & 1 & 5 & 3 & & \\
\hline 21 & P04.11 & 11,1 & 7 & 1 & 1 & & \\
\hline 22 & & 11,2 & 2 & 3 & 4 & & \\
\hline 23 & P08.1 & 1,1 & 1 & 2 & 6 & & \\
\hline 24 & & 1,2 & 1 & 2 & 6 & & \\
\hline 25 & P08.2 & 2,1 & 1 & 6 & 2 & & \\
\hline 26 & & 2,2 & 4 & 5 & & & \\
\hline 27 & P08.3 & 3,1 & & 2 & 7 & & \\
\hline 28 & & 3,2 & & 3 & 5 & 1 & \\
\hline 29 & P08.4 & 4,1 & 5 & 4 & & & \\
\hline 30 & & 4,2 & 1 & 5 & 3 & & \\
\hline 31 & P08.5 & 5,1 & 3 & 5 & 1 & & \\
\hline 32 & & 5,2 & 1 & 5 & 3 & & \\
\hline 33 & P08.6 & 6,1 & 3 & 4 & 2 & & \\
\hline 34 & & 6,2 & & 4 & 5 & & \\
\hline
\end{tabular}

JLH

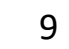

9

9

9

9

9

9

9

9

9
9

9

9

9

9

9

9

9

9

9

9

9

9

9

9

9

9

9

9

9

9

9

9

9
9

EXPECTED

\begin{tabular}{|c|c|c|c|c|c|}
\hline SB & B & C & TB & STB & JLH \\
\hline $\mathbf{8}$ & $\mathbf{1}$ & & & 9 \\
$\mathbf{4}$ & $\mathbf{1}$ & & & & 5 \\
\hline 8 & 1 & & & & \\
\hline
\end{tabular}




\begin{tabular}{|c|c|c|c|c|}
\hline 2,13 & & 1,60 & & \\
\hline 2,47 & \multirow{2}{*}{2,27} & 2,93 & \multirow{2}{*}{2,80} & \multirow[b]{2}{*}{0,53} \\
\hline 2,07 & & 2,67 & & \\
\hline 2,53 & \multirow{2}{*}{2,43} & 2,93 & \multirow{2}{*}{2,90} & \multirow[b]{2}{*}{0,47} \\
\hline 2,33 & & 2,87 & & \\
\hline 2,00 & \multirow{2}{*}{1,93} & 2,53 & \multirow{2}{*}{2,50} & \multirow[b]{2}{*}{0,57} \\
\hline 1,87 & & 2,47 & & \\
\hline 2,33 & \multirow{2}{*}{2,27} & 2,87 & \multirow{2}{*}{2,77} & \multirow[b]{2}{*}{0,50} \\
\hline 2,20 & & 2,67 & & \\
\hline 2,53 & \multirow{2}{*}{2,60} & 3,00 & \multirow{2}{*}{2,97} & \multirow[b]{2}{*}{0,37} \\
\hline 2,67 & & 2,93 & & \\
\hline 2,20 & \multirow{2}{*}{2,13} & 2,80 & \multirow{2}{*}{2,73} & \multirow[b]{2}{*}{0,60} \\
\hline 2,07 & & 2,67 & & \\
\hline 2,33 & \multirow{2}{*}{2,40} & 2,80 & \multirow{2}{*}{2,90} & \multirow[b]{2}{*}{0,50} \\
\hline 2,47 & & 3,00 & & \\
\hline 2,13 & \multirow{2}{*}{2,03} & 2,73 & \multirow{2}{*}{3,00} & \multirow[b]{2}{*}{0,97} \\
\hline 1,93 & & 3,27 & & \\
\hline 2,60 & \multirow{2}{*}{2,43} & 3,00 & \multirow{2}{*}{2,90} & \multirow[b]{2}{*}{0,47} \\
\hline 2,27 & & 2,80 & & \\
\hline 2,80 & \multirow{2}{*}{2,53} & 2,93 & \multirow{2}{*}{2,83} & \multirow[b]{2}{*}{0,30} \\
\hline 2,27 & & 2,73 & & \\
\hline 2,07 & & 2,60 & & \\
\hline 2,07 & 2,07 & 2,60 & 2,60 & 0,53 \\
\hline 2,33 & 250 & 2,87 & 293 & \\
\hline 2,67 & 2,50 & 3,00 & 2,93 & 0,43 \\
\hline 1,93 & 193 & 2,53 & 273 & \\
\hline 1,93 & د, & 2,93 & & 0,80 \\
\hline 2,73 & 250 & 3,00 & 2.90 & 0.40 \\
\hline 2,27 & 2,50 & 2,80 & & \\
\hline 2,53 & 240 & 2,93 & 287 & 0,47 \\
\hline 2,27 & 2,40 & 2,80 & & 0,41 \\
\hline 2,47 & 27 & 3,00 & 283 & 0.57 \\
\hline 2,07 & 2,21 & 2,67 & & \\
\hline
\end{tabular}

REKAP HASIL KUESIONER

MANAGEMENT

PERFORMANCE

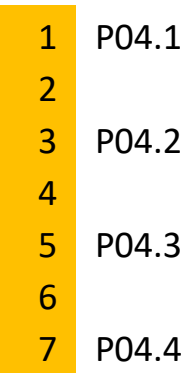

\begin{tabular}{|c|r|}
\hline No & PB \\
\hline 1,1 & \\
1,2 & \\
2,1 & \\
2,2 & \\
3,1 & \\
3,2 & \\
4,1 &
\end{tabular}

\begin{tabular}{l|l|l|l|l} 
SB & B & C & TB & STB \\
\hline
\end{tabular}

JLH

4

4

$\begin{array}{ll} & \\ 4 & 4 \\ 4 & \\ 4 & \end{array}$

EXPECTED

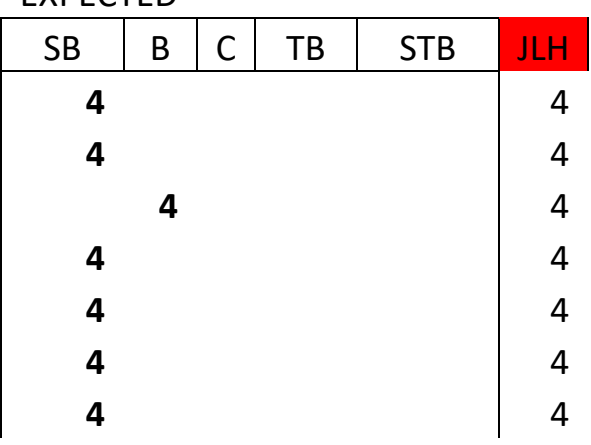




\begin{tabular}{|c|c|c|c|c|}
\hline 8 & & 4,2 & & \\
\hline 9 & P04.5 & 5,1 & & 4 \\
\hline 10 & & 5,2 & & 4 \\
\hline 11 & P04.6 & 6,1 & & 4 \\
\hline 12 & & 6,2 & 4 & \\
\hline 13 & P04.7 & 7,1 & & 4 \\
\hline 14 & & 7,2 & 4 & \\
\hline 15 & P04.8 & 8,1 & & 4 \\
\hline 16 & & 8,2 & 4 & \\
\hline 17 & P04.9 & 9,1 & & 4 \\
\hline 18 & & 9,3 & 4 & \\
\hline 19 & P04.10 & 10,1 & & 1 \\
\hline 20 & & 10,2 & & 4 \\
\hline 21 & P04.11 & 11,1 & & 4 \\
\hline 22 & & 11,2 & & 4 \\
\hline 23 & P08.1 & 1,1 & & 4 \\
\hline 24 & & 1,2 & & 4 \\
\hline 25 & P08.2 & 2,1 & & 4 \\
\hline 26 & & 2,2 & & 4 \\
\hline 27 & P08.3 & 3,1 & 4 & \\
\hline 28 & & 3,2 & & 2 \\
\hline 29 & P08.4 & 4,1 & 4 & \\
\hline 30 & & 4,2 & & 4 \\
\hline 31 & P08.5 & 5,1 & 4 & \\
\hline 32 & & 5,2 & 4 & \\
\hline 33 & P08.6 & 6,1 & 4 & \\
\hline & & 6,2 & & 4 \\
\hline
\end{tabular}

\begin{tabular}{|l|ll}
4 & & 4 \\
4 & 4 & \\
4 & 4 & \\
4 & 4 & \\
4 & 4 & \\
4 & 4 & \\
4 & 4 & \\
4 & 4 & \\
4 & 4 & \\
4 & 4 & \\
4 & 4 & \\
4 & 1 & 3 \\
4 & 4 & \\
4 & 4 & \\
4 & 4 & \\
4 & 4 & \\
4 & 4 & \\
4 & 4 & \\
4 & 4 & \\
4 & 4 & \\
4 & 2 & 2 \\
4 & 4 & \\
4 & & 4 \\
4 & 4 & \\
4 & 4 & \\
4 & 4 & \\
4 & 4 &
\end{tabular}

\begin{tabular}{|c|c|c|c|c|}
\hline \multicolumn{2}{|c|}{ PERFORMANCE } & \multicolumn{2}{|c|}{ EXPECTED } & \multirow{3}{*}{ gap } \\
\hline \multicolumn{4}{|c|}{ MATURITY } & \\
\hline ACTIVITY & PROSES & ACTIVITY & PROSES & \\
\hline 3,20 & \multirow{2}{*}{3,60} & 4,00 & \multirow{2}{*}{4,00} & \multirow[b]{2}{*}{0,40} \\
\hline 4,00 & & 4,00 & & \\
\hline 2,40 & \multirow{2}{*}{2,80} & 3,20 & \multirow{2}{*}{3,60} & \multirow[b]{2}{*}{0,80} \\
\hline 3,20 & & 4,00 & & \\
\hline 4,00 & \multirow{2}{*}{3,60} & 4,00 & \multirow{2}{*}{4,00} & \multirow[b]{2}{*}{0,40} \\
\hline 3,20 & & 4,00 & & \\
\hline 3,20 & \multirow{2}{*}{2,80} & 4,00 & \multirow{2}{*}{3,60} & \multirow[b]{2}{*}{0,80} \\
\hline 2,40 & & 3,20 & & \\
\hline 3,20 & \multirow{2}{*}{3,20} & 4,00 & \multirow{2}{*}{4,00} & \multirow[b]{2}{*}{0,80} \\
\hline 3,20 & & 4,00 & & \\
\hline 3,20 & \multirow{2}{*}{3,60} & 4,00 & \multirow{2}{*}{4,00} & \multirow[b]{2}{*}{0,40} \\
\hline 4,00 & & 4,00 & & \\
\hline 3,20 & \multirow{2}{*}{3,60} & 4,00 & \multirow{2}{*}{4,00} & \multirow[b]{2}{*}{0,40} \\
\hline 4,00 & & 4,00 & & \\
\hline 3,20 & \multirow{2}{*}{3,60} & 4,00 & \multirow{2}{*}{4,00} & \multirow[b]{2}{*}{0,40} \\
\hline 4,00 & & 4,00 & & \\
\hline
\end{tabular}




\begin{tabular}{|c|c|c|c|c|}
\hline $\begin{array}{l}3,20 \\
4,00\end{array}$ & 3,60 & $\begin{array}{l}4,00 \\
4,00\end{array}$ & 4,00 & 0,40 \\
\hline 2,60 & \multirow{2}{*}{2,90} & 3,40 & \multirow{2}{*}{3,70} & \\
\hline 3,20 & & 4,00 & & 0,80 \\
\hline 3,20 & \multirow{2}{*}{3,20} & 4,00 & \multirow{2}{*}{4,00} & \\
\hline 3,20 & & 4,00 & & 0,80 \\
\hline 3,20 & \multirow{2}{*}{3,20} & 4,00 & \multirow{2}{*}{4,00} & \\
\hline 3,20 & & 4,00 & & 0,80 \\
\hline 3,20 & \multirow{2}{*}{3,20} & 4,00 & \multirow{2}{*}{4,00} & \\
\hline 3,20 & & 4,00 & & 0,80 \\
\hline 4,00 & \multirow{2}{*}{3,40} & 4,00 & \multirow{2}{*}{3,80} & \\
\hline 2,80 & & 3,60 & & 0,40 \\
\hline 4,00 & \multirow{2}{*}{3,60} & 4,00 & \multirow{2}{*}{3,60} & \multirow{2}{*}{0,00} \\
\hline 3,20 & & 3,20 & & \\
\hline 4,00 & \multirow{2}{*}{4,00} & 4,00 & \multirow{2}{*}{4} & \\
\hline 4,00 & & 4,00 & & 0,00 \\
\hline 4,00 & \multirow{2}{*}{3,60} & 4,00 & \multirow{2}{*}{4,00} & \\
\hline 3,20 & & 4,00 & & $-0,40$ \\
\hline
\end{tabular}

\section{Perhitungan User \& Manajement}

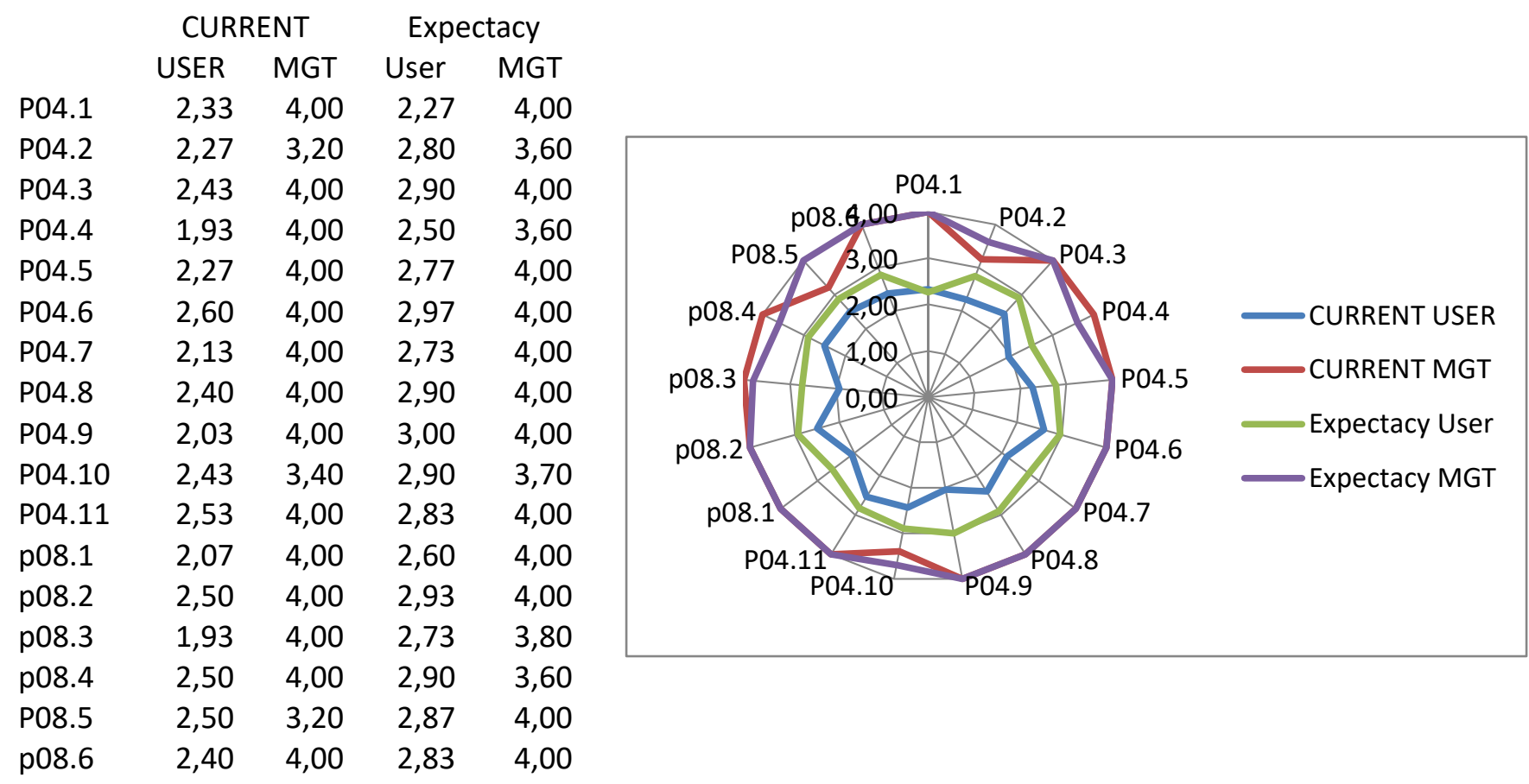

\section{Perhitungan USER}

$\begin{array}{cr}\text { CURRENT } & \text { Expectacy } \\ \text { USER } & \text { User } \\ 2,33 & 2,93 \\ 2,27 & 2,93 \\ 2,43 & 2,93 \\ 1,93 & 2,53 \\ 2,27 & 2,87\end{array}$




$\begin{array}{lll}\text { P04.6 } & 2,60 & 3,00 \\ \text { P04.7 } & 2,13 & 2,80 \\ \text { P04.8 } & 2,40 & 2,80 \\ \text { P04.9 } & 2,03 & 2,73 \\ \text { P04.10 } & 2,43 & 3,00 \\ \text { P04.11 } & 2,53 & 2,93 \\ \text { P08.1 } & 2,07 & 2,60 \\ \text { P08.2 } & 2,50 & 2,87 \\ \text { P08.3 } & 2,50 & 3,00 \\ \text { P08.4 } & 2,40 & 2,40 \\ \text { P08.5 } & 2,27 & 2,27 \\ \text { P08.6 } & 0,00 & 0,00\end{array}$

\section{Perhitungan Manajement}

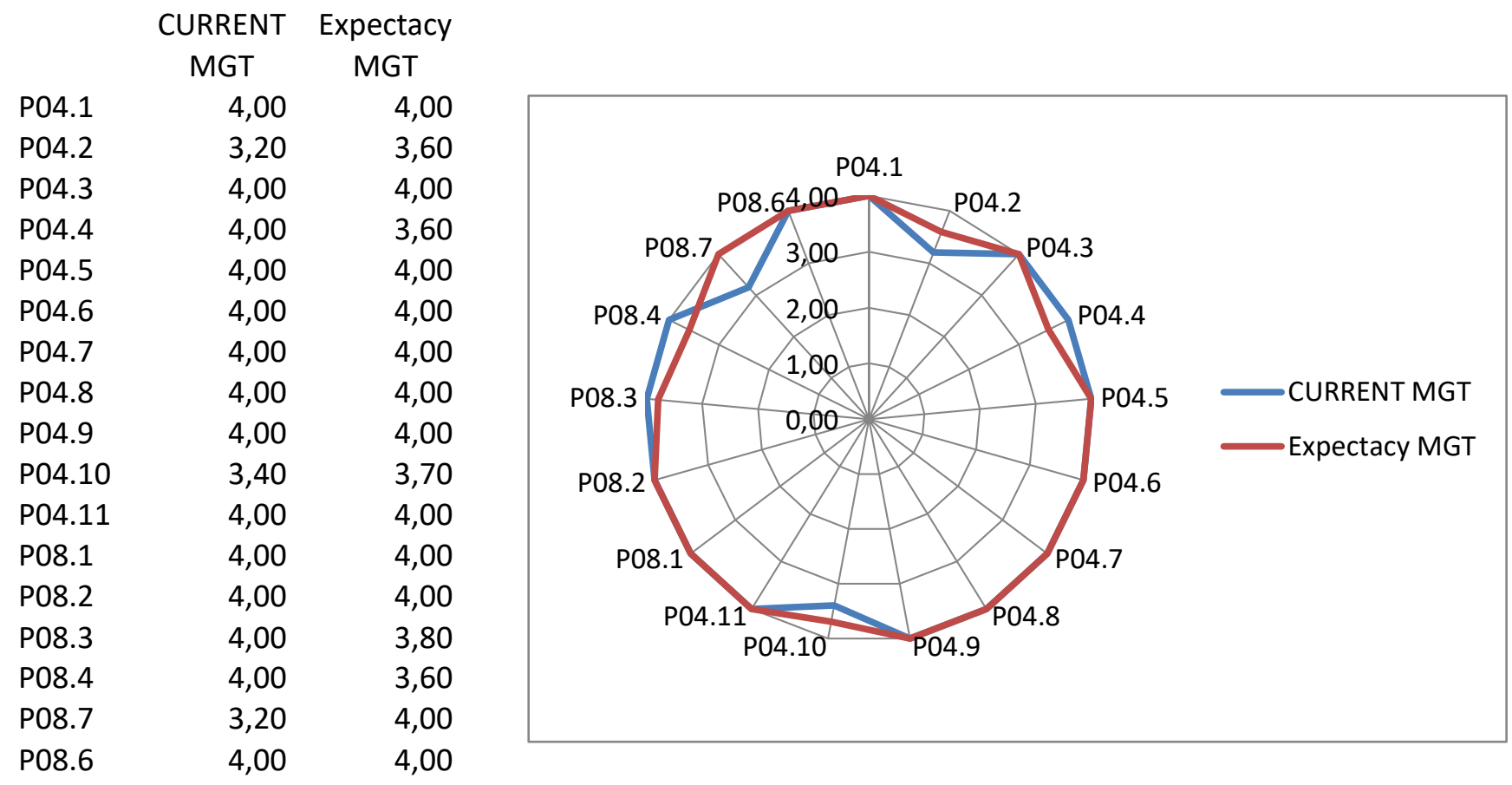




\section{BAB V}

\section{Saran}

- Dapat menegur siswa/i dengan cara yang lebih baik lagi .

- Memberikan kosekuensi kepada siswa yang melanggar peraturan sekolah

- Lebih menjaga data-data yang berada diperpustaan serta data bimbingan konsling

\section{Kesimpulan}

Dari hasil audit yang dilakukan di SMK FARMASI CENDIKIA FARMA HUSADA sudah cukup baik dalam segi bimbingan konseling \& penataan pada perpustaan yang berada di dalam sekolah, hanya saja harus dapat diperbaiki dalam segi menyampaikan sesuatu hal disetiap kelasnya yang berhubungan dengan siswa/i. 


\section{LAMPIRAN}

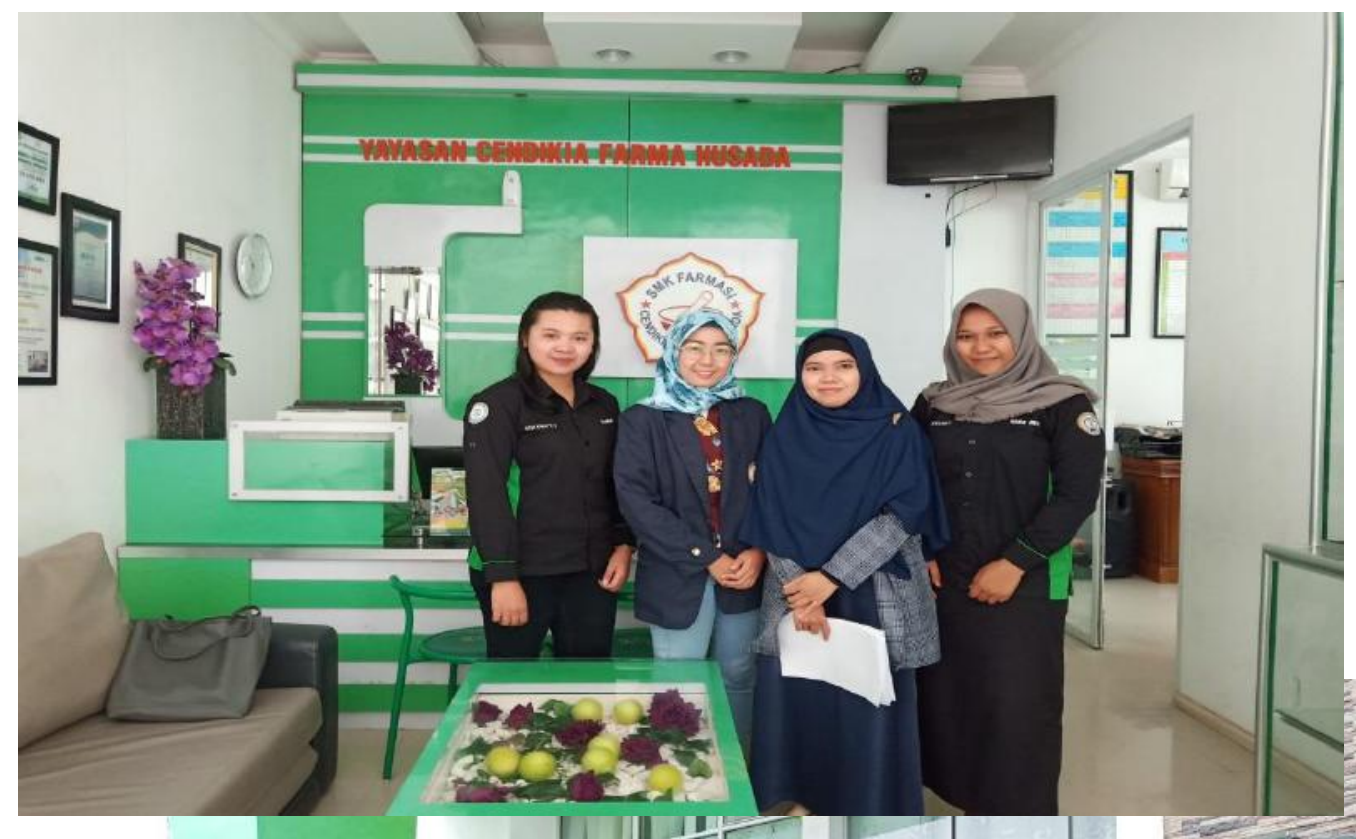

Saren Ser -5 kistit

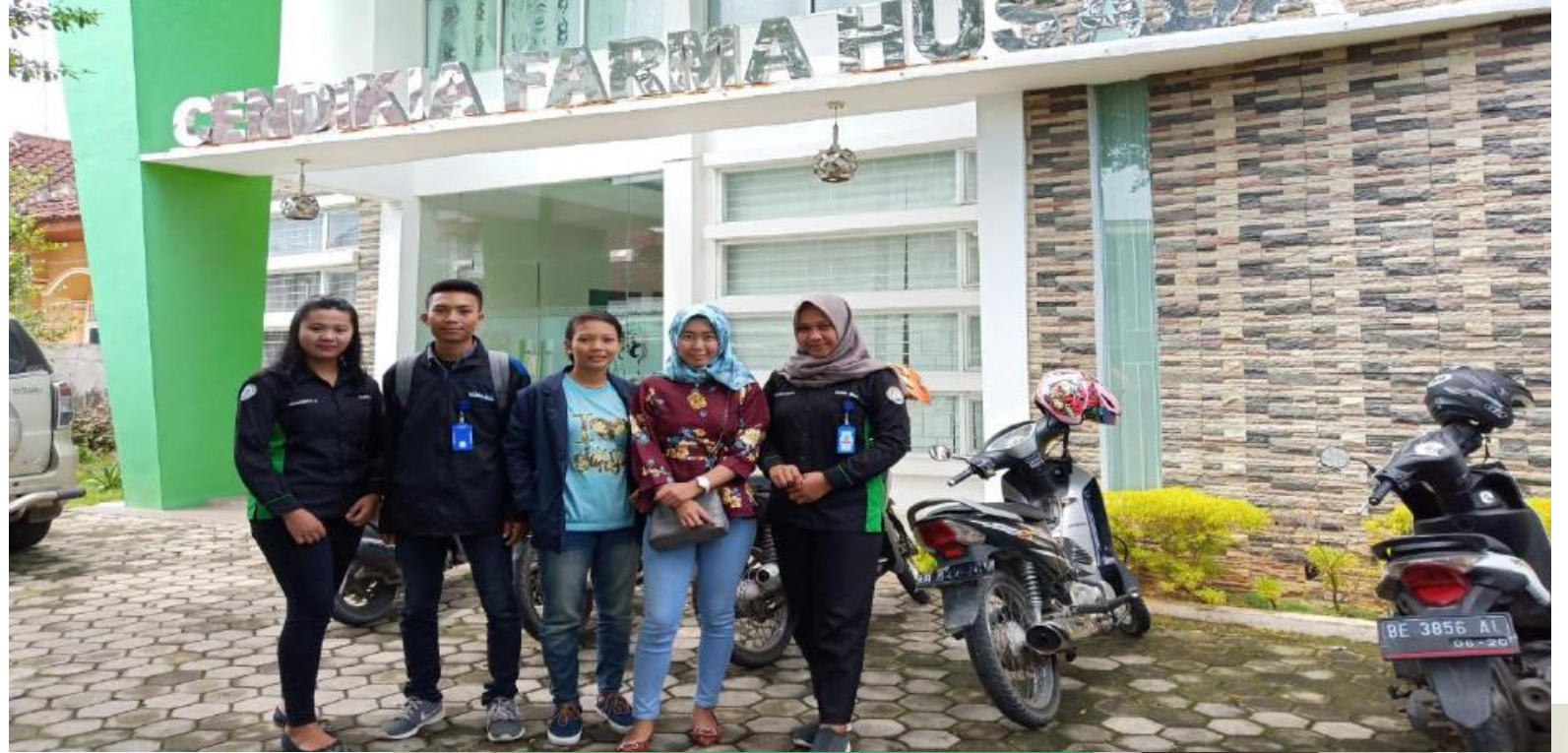

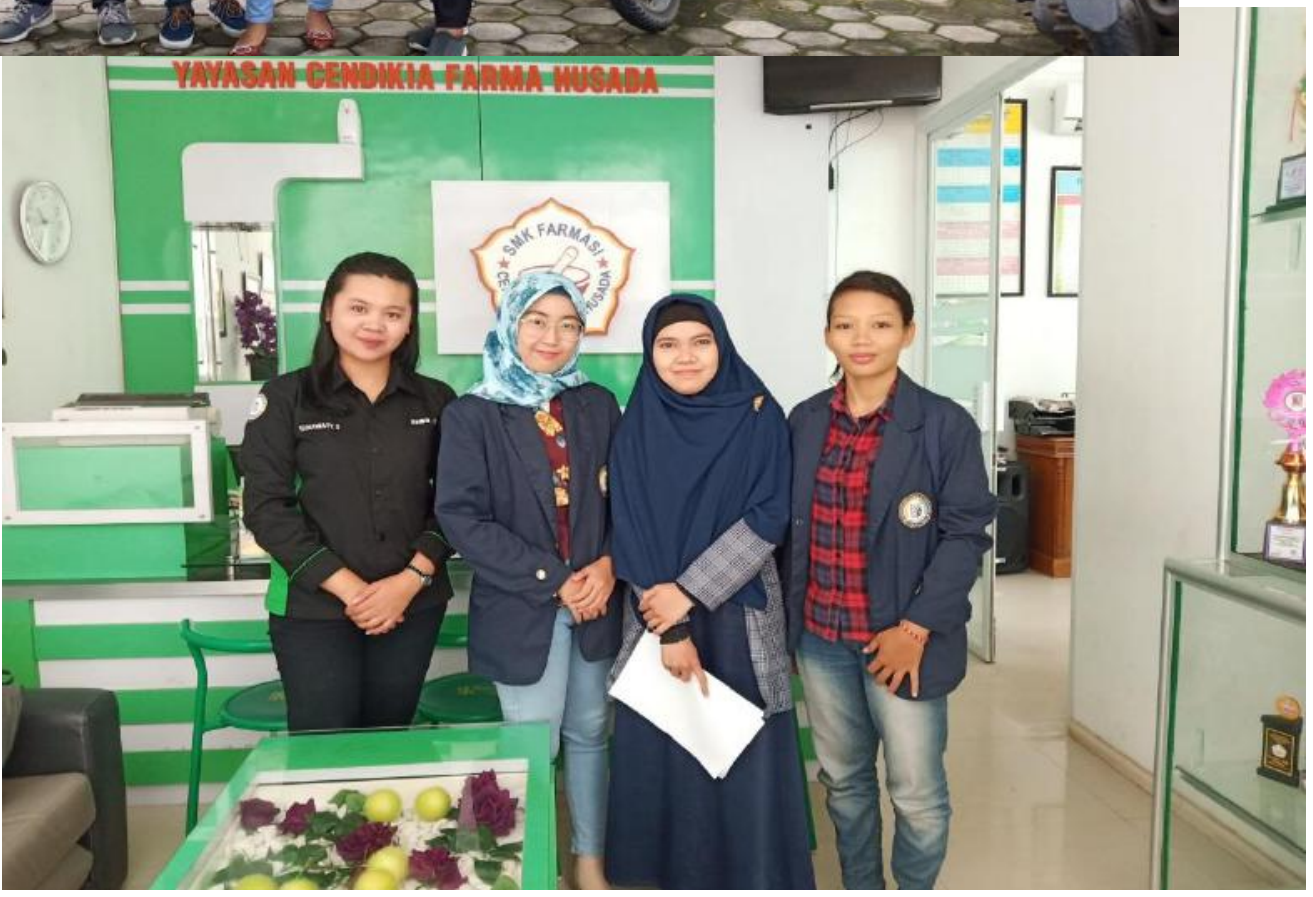

